\title{
EVALUATION OF THE SUITABILITY OF THE STRAIN-GAUGE METHOD FOR MEASURING DEFORMATIONS DURING THE FATIGUE TESTS OF AVIATION COMPOSITE STRUCTURES
}

\author{
Marek Rośkowicz, Piotr Leszczyński \\ Military University of Technology, Poland
}

\begin{abstract}
The paper discusses the results of selected fatigue tests of a motor glider's insulated spar structure. The results of the experimental tests were used to assess the potential of the strain-gauge method for diagnosing the spar damage involving the unbolting of one of metal fittings in the spar pin. The usefulness of the deformation measurement method in the composite structure diagnostic process was confirmed, while simultaneously drawing attention to the need for conducting a process optimizing the number of sensors and their distribution on a tested object, in the context of the sensitivity of diagnostic signals received.
\end{abstract}

Keywords: aviation composite structures, fatigue tests, strain-gauge method, deformation measurements.

\section{INTRODUCTION}

Composite materials, which are increasingly common in aviation structures including primary elements, should be effectively diagnosed in the course of their operation. The diagnostic process is, however, hindered due to fatigue damage formation and development in composites being quite different than in metallic materials. Their hard to detect nature, frequent lack of surface signs of fatigue, the presence of damage in the form of intra-bedding or inter-bedding delaminations, and a very rapid damage process of cyclically loaded material, enforce an intensive development of diagnostic methods, effective not only in the process of composite aviation structures maintenance, but also within their operating process $[1,2,4]$.

Methods effectively used for detecting damage during the maintenance process of composite aviation structures include ultra-sound, thermographic and optical (shearography). In the case of operating aircraft with composite elements, the effective diagnostic procedures are based on acoustic emission methods and the measurements of deformations within a strained structure. 
A group of relatively cost effective methods of analysing composite structures includes a procedure based on measuring deformations with the use of strain gauges. The method can be used both at low and high temperatures, under changing pressure and at high humidity. An additional advantage of this method is the fact that the fastened sensors do not affect the continuity of the structure, and do not adversely impact the strength parameters of the material $[6,7,8]$. The number of sensors to be installed on an element diagnosed depends on a number of factors. Modern calculating tools based on the Finite Elements Method can be used for the difficult task of selecting the number of strain gauges and their installation locations [5]. They can be used to select the locations at which deformation change measurement will "generate" the most effective diagnostic information.

The objective of the conducted tests was to assess the potential of the strain gauge method for evaluating the technical condition of a primary composite aviation structure - an aviation spar. Because the weak spot in a composite structure is the nodes "transferring" concentrated loads, the diagnostic process in the presented analysis mainly concerned two spar nodes, with non-adhesive metal-composite joint. The conducted diagnostic tests based on strain sensors were supplemented with thermographic tests with the use of a thermal imaging camera.

\section{EXPERIMENTAL TESTS}

Own tests involved using a composite spar of an AOS-71 glider. The spar was constructed in composite technology, known as wet carbon fibres and carbon roving [3]. We can distinguish three structural elements of the spar: a pin with fittings, spar caps and a wall with reinforcement. The cross-section of the spar has the form of a double-tee bar. Fig. 1. shows the spar model with its main dimensions.

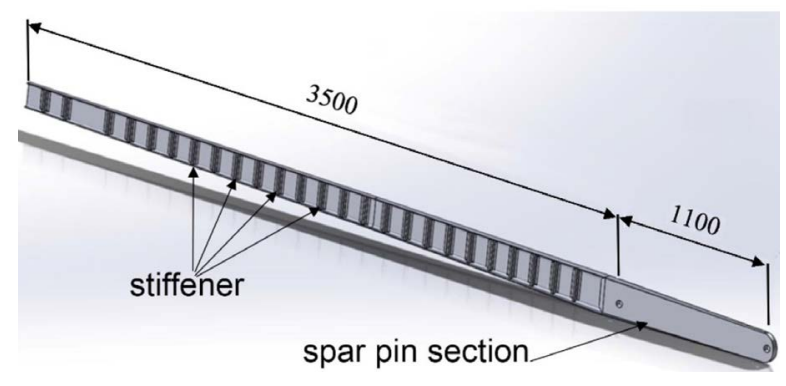

Fig. 1. Spar model

The following materials were used for constructing the spar: SGL KDK 8042 carbon fabric, Toryaca T700G carbon roving, DIV 60 foam and L285/ H285 epoxy resin saturant. 
A test bench was designed and constructed for the purpose of the experimental tests. The tested composite spar was mounted on a load floor with two triangular supports. The spar movement in all three planes was restricted in support of node no. 2, while the movement of the spar in the spar wall plane was enabled in the support of node no. 1 - fig. 2. This method of spar mounting corresponds to the spar installation conditions in a motor glider.

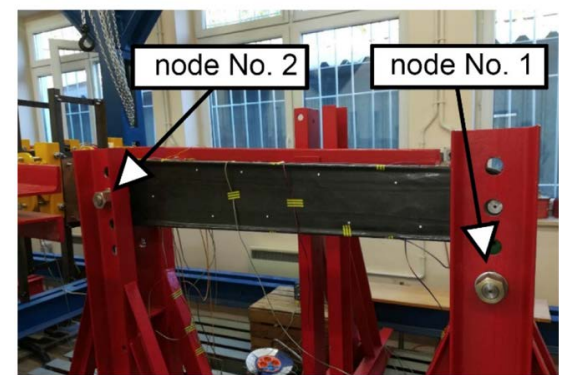

Fig. 2. Spar nodes

An additional system of cross-rails was designed and constructed in order to protect the spar against uncontrolled transverse deformation, and to reflect the spar installation conditions in the motor glider wing. For this purpose, twentytwo prolab blocks (11 blocks each side) were glued symmetrically to the wall of the spar and constituted the base for the installation of the roller system races. The races were made from a steel $30 \times 30 \times 2 \mathrm{~mm}$ tee-bar. In order to increase the stiffness of the auxiliary system, crossbars made from a $30 \times 2 \mathrm{~mm}$ flat bar were fixed between the tee-bars. Another element of the cross-rail system were 5, 3 or 2 rollers installed in additional auxiliary beams. The number of rollers installed in the auxiliary beams resulted from the value of the spar's displacement in the plane of its load. The method for mounting the spar in the test bench and an additional cross-rail system is shown in fig. 3 .

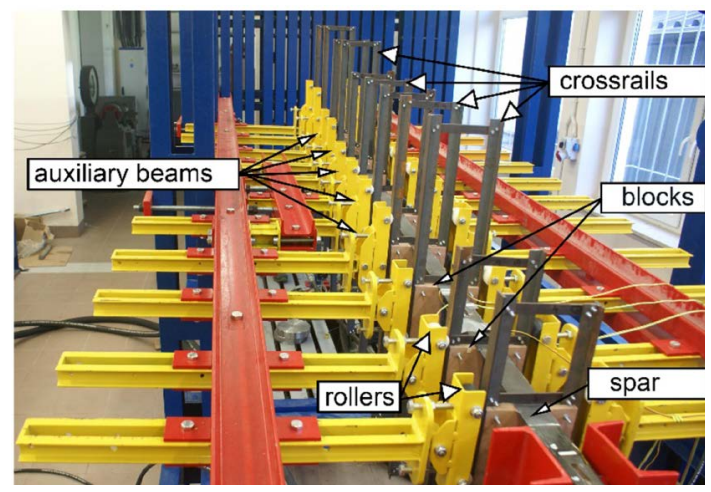

Fig. 3. The method for mounting the spar on the test bench 
The composite spar was cyclically loaded with a Bosch Rexroth hydraulic cylinder, fastened from one side to a load floor and to the spar from the other side, using a special clamp. A force gauge was also attached to the cylinder, for use in the load control system - fig. 4.

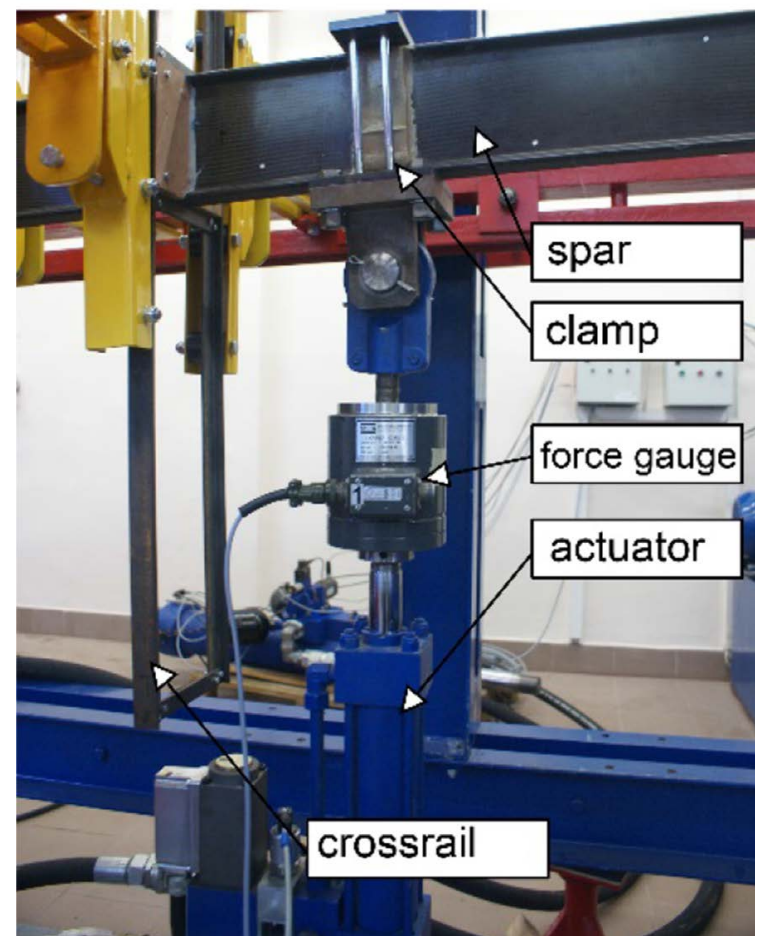

Fig. 4. Spar loading system

The spar deformations at selected locations, the force and spar displacement over the cylinder plane were recorded during the fatigue tests. The tensometric system used for measuring the deformations utilized 19 sensors, including: 15 strain gauges with a $300 \mathrm{Ohm}$ specific resistance and 4 strain gauges with a $120 \mathrm{Ohm}$ specific resistance. The strain gauges were attached in the following manner: 3 rosettes on the spar wall and pin - first rosette $550 \mathrm{~mm}$ away from the first fitting (node no. 1), the second rosette by the second fitting (node no. 2) and the third rosette at $600 \mathrm{~mm}$ from node no. 2, towards the spar tip, 4 strain gauges on spar caps in its transverse plane, and 6 strain gauges along the spar caps. Fig. 5 shows the distribution of all 19 strain gauges installed on the spar. 


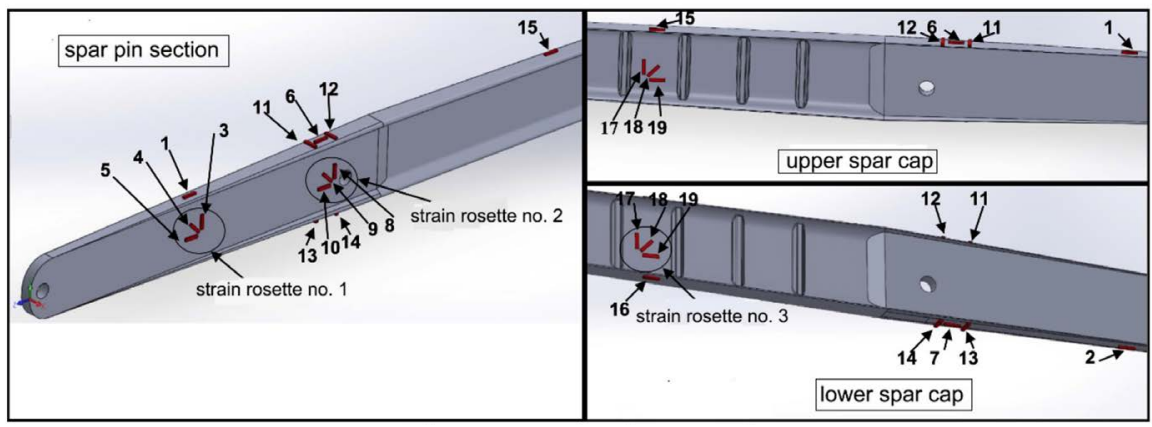

Fig.5. Strain gauge distribution on the pin

Two tests of cyclical spar loading were conducted, each containing 1000 cycles, with a change frequency of $0.25 \mathrm{~Hz}$. With the use of a hydraulic system, the spar deflection was induced at the cylinder installation point, in an almost swing cycle, over the range of $48.8 \mathrm{~mm}$ towards the load floor (downward displacement - driving force of $1560 \mathrm{~N}$ ) and $51.2 \mathrm{~mm}$ towards the room ceiling (upward displacement - driving force of $1700 \mathrm{~N}$ ) from its neutral position. The second test involved diagnosing the technical condition of the spar at node no. 2 nut untightening by about $60^{\circ}$. Spar fittings were made as non-adhesive composite-metal joints, and the metallic elements of the node installed with bolted connections were protected against unscrewing through stippling on the spar lock nut - fig. 6 .

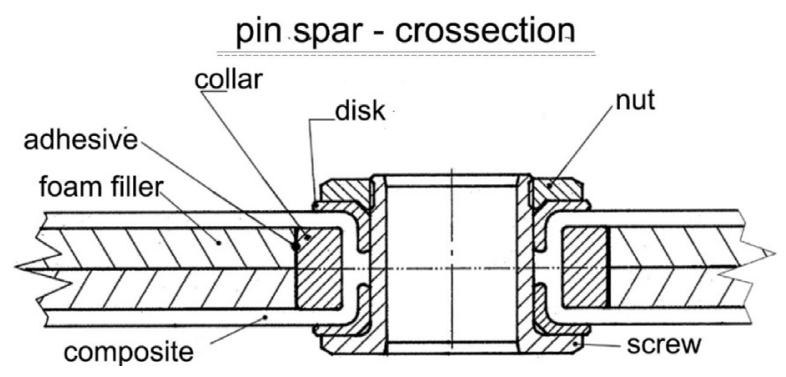

Fig. 6. Spar cross-section in the fitting area

\section{RESULTS OF EXPERIMENTAL TESTS}

The execution of the experimental tests provided deformation change courses, the nature of which corresponded to a spar swing load cycle. Six deformation values in individual measuring channels were recorded for half of the cycle. Examples of a deformation change course for the 1500th and 1000th cycle in 16 measuring channels are shown in fig. 7. 


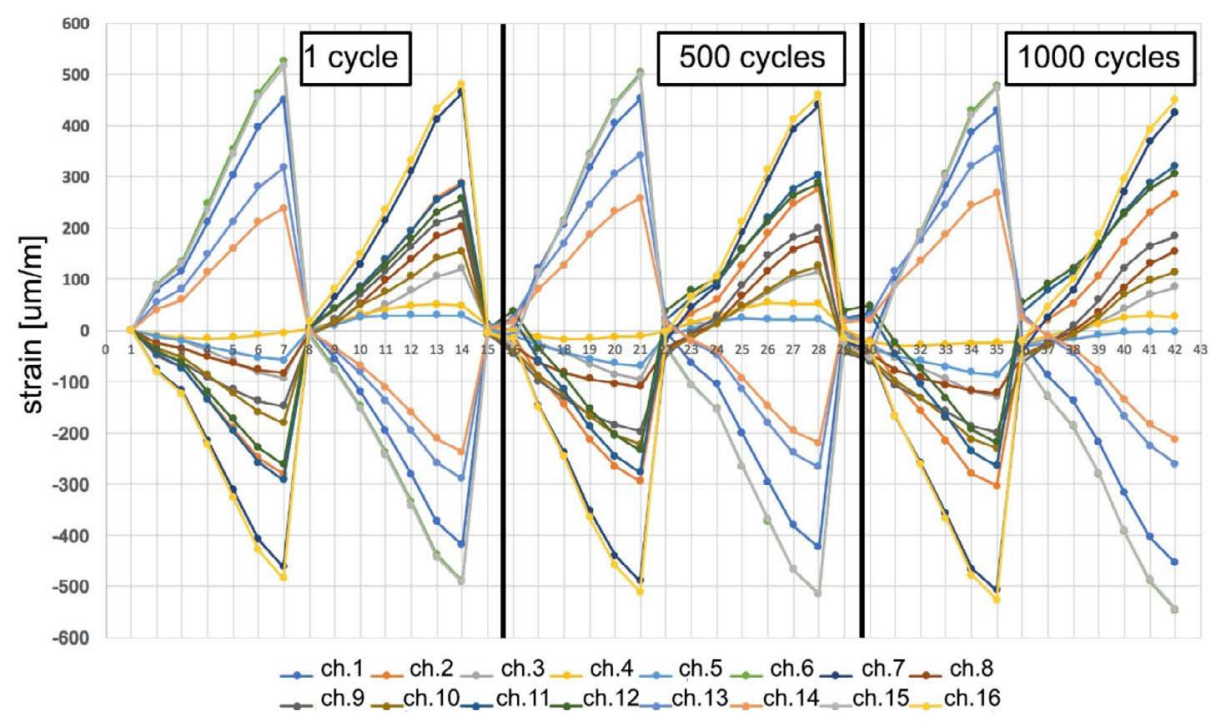

Fig. 7. Course of deformation changes

Figs. 8 and 9 compare the deformation courses recorded by strain gauges attached to the spar cap for two analysed cases: fitting of node no. 2 installed correctly and the nut of node no. 2 fitting "loosened" by $60^{\circ}$ (the "prim" signs marks the second case in the figures). Deformations recorded in the spar caps for the two cases in question were compared and could not have constituted a diagnostic parameter for the case of spar fitting damage under consideration (a low-sensitivity signal). Greater deformation changes were observed when analysing the maximum primary deformations recorded by the strain gauge rosettes fixed to the spar wall (fig. 10 and fig. 11), while bigger differences of maximum primary deformations were present in the rosette no. 1 installation area (including the change of the deformation sign). The maximum primary deformations of rosette no. 1 were significantly impacted by constituent deformations of strain gauge no. 4 (fig. 12), which changed along with the number of load cycles and the observed phenomenon of further self-unscrewing of the fitting nut. 


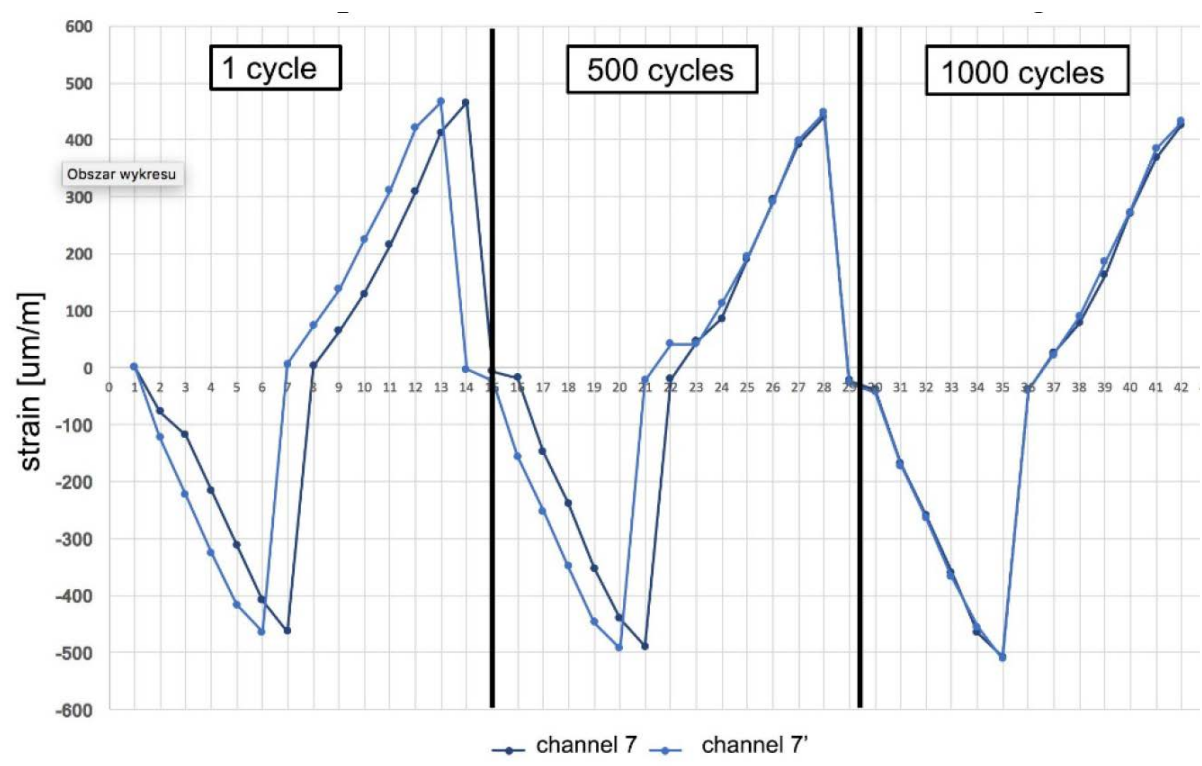

Fig. 8. The course of strain gauge deformations in channel 7 (for a tightened and unscrewed fitting)

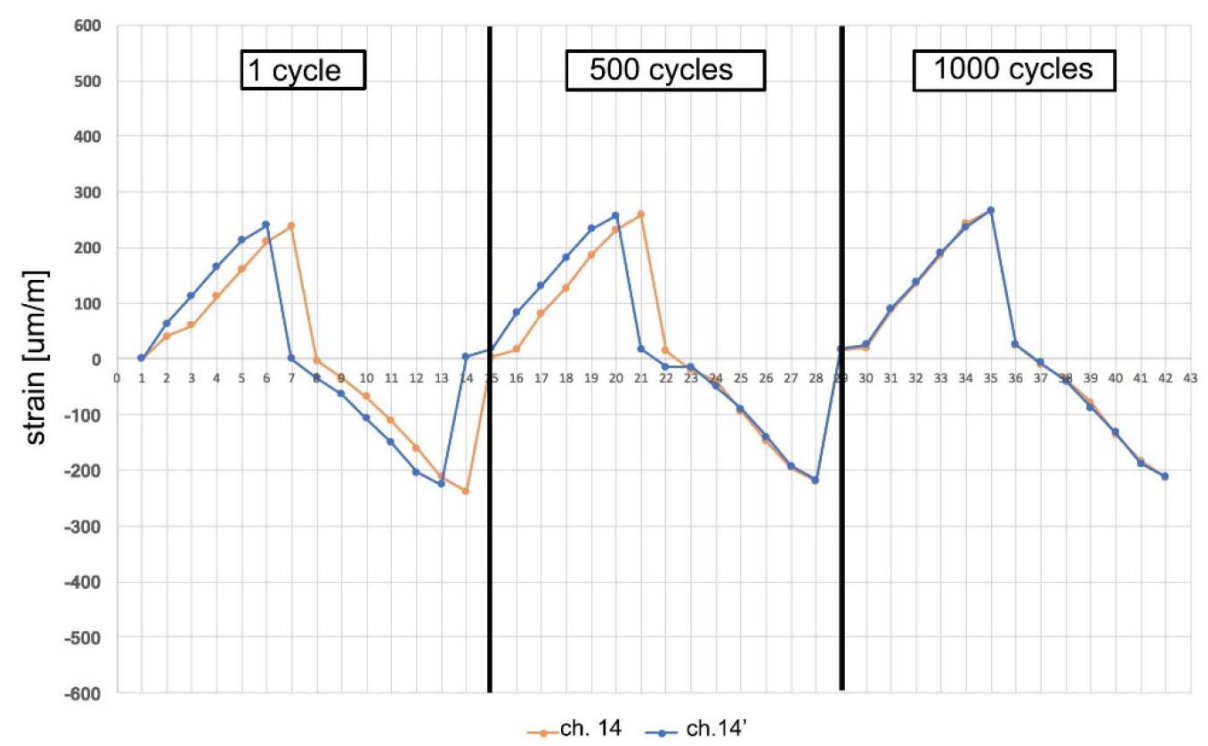

Fig. 9. The course of strain gauge deformations in channel 14 (for a tightened and unscrewed fitting) 


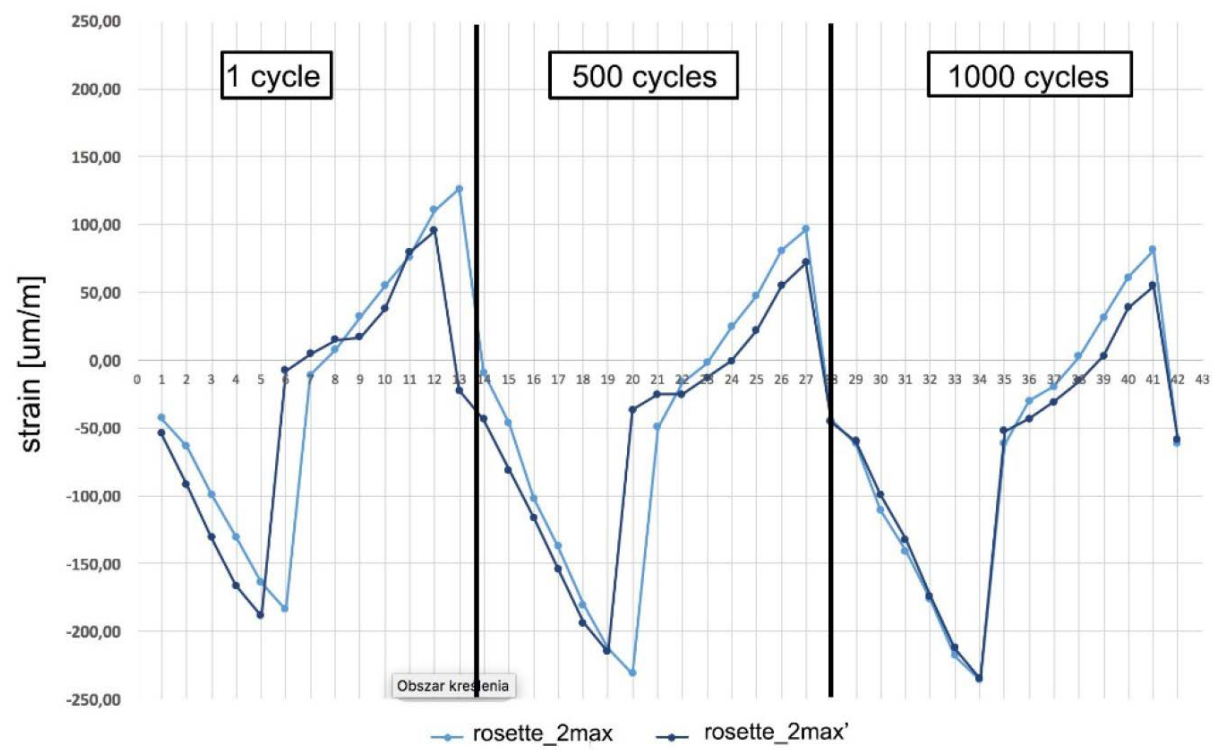

Fig. 10. The course of rosette no. 2 maximum primary deformations (for a tightened and unscrewed fitting)

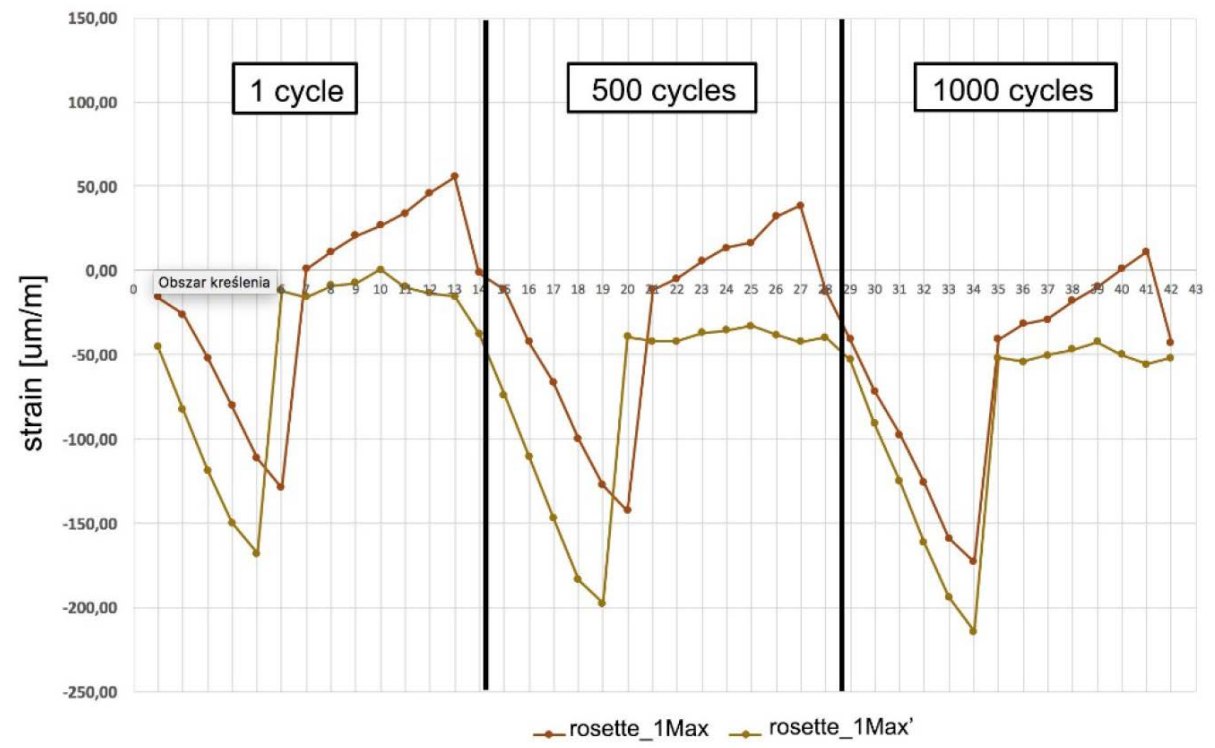

Fig. 11. The course of rosette no. 1 maximum primary deformations (for a tightened and unscrewed fitting) 


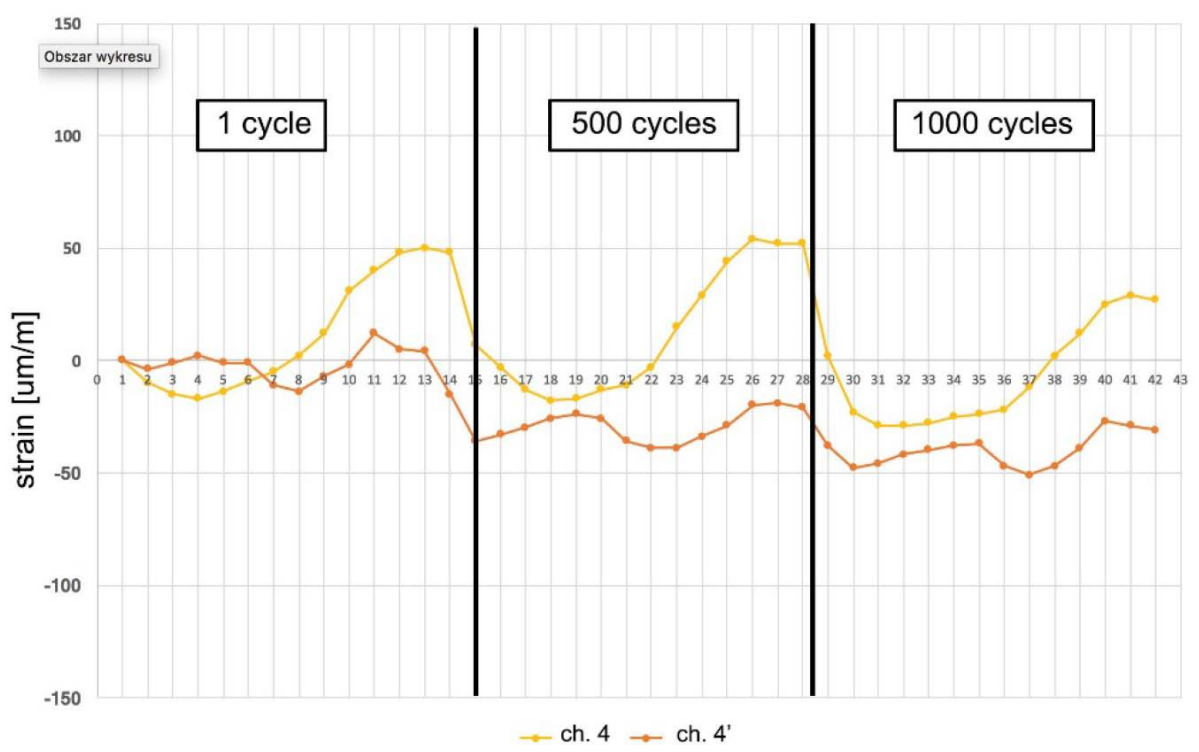

Fig. 12. The course of strain gauge deformations in channel 4 (for a tightened and unscrewed fitting)

The spar pin was also observed during the tests, with the use of a thermal imaging camera. No significant changes of pin fitting temperature were recorded, while the low thermal conductivity of the spar material could have been the reason for a significant temperature increase at strain gauge rosette installation points in the course of the fatigue tests - fig. 13.

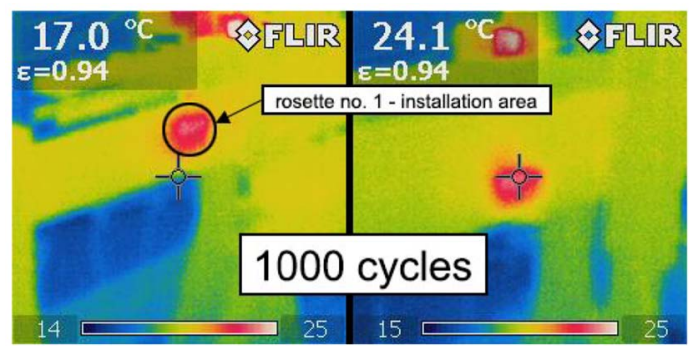

Fig. 13. Temperature change in the installation area of rosette no. 1 (from $17^{\circ} \mathrm{C}$ to $24.1^{\circ} \mathrm{C}$ )

\section{CONCLUSIONS}

Based on the conducted experimental tests of an AOS-71 motor glider composite spar, it was concluded that:

- the method of a composite structure technical condition diagnostics implemented with the use of strain gauges may be useful not only for 
evaluating the formation and development of typical fatigue damage in composite polymer material, but also for diagnosing operating damage resulting from the operation of structural systems consisting of numerous inter-connected elements, in variable conditions;

- only the signals from selected sensors turned out to be useful in the diagnostic process - hence the need to conduct an optimization of the number of sensors used and their distribution, taking into account the diagnostic sensitivity of received signals to typical structural damage;

- if a structure is made from composite polymer materials, the strain gauge design process of a diagnostic system should also take into account the phenomenon of low thermal conductivity of such materials, as well as the phenomenon of the heating up of cyclically loaded sensors (the need to use compensating sensors);

- the non-adhesive spar fitting installation method used can be replaced with an effective method of joining structural elements with adhesive assembly plastics - thus eliminating the issues associated with self-unscrewing of screw elements.

\section{REFERENCES}

[1] Glass Andrzej, Murawski Tomasz: „Polskie szybowce 1945-2011. Problemy rozwoju" [Polish gliders 1945-2011. Development issues], Wydawnictwo SCG.

[2] Rodzewicz Mirosław: „Spektra obciążeń i trwałość zmęczeniowa struktury nośnej szybowców kompozytowych" [Load spectra and fatigue durabiliy of a composite glider load-bearing structure], Oficyna Wydawnicza Politechniki Warszawskiej.

[3] „Technologia ramowa wykonania dźwigarów skrzydeł” [Frame technology for the execution of wing spars], Politechnika Warszawska, Warszawa, listopad 2010.

[4] Orkisz Marek, Święch Łukasz, Zacharzewski Jan: „Badania zmęczeniowe kompozytowego dźwigara skrzydła motoszybowca" [Fatigue tests of a motor glider wing composite spar].

[5] Łaczek Stanisław: „Przykłady analizy konstrukcji w systemie MES Ansys-Workbench V.12.1" [Examples of structural analysis in the MES Ansys-Workbench V.12.1 system], Wydawnictwo Politechniki Krakowskiej.

[6] Roliński Zygmunt: „Tensometria oporowa. Podstawy teoretyczne i przykłady zastosowań" [Resistance tensometry. Theoretical basis and examples of application], Wydawnictwa Naukowo-Techniczne, Warszawa 1981.

[7] Praca zbiorowa: „Mechanika techniczna. Laboratorium” [Technical mechanics. Laboratory], Oficyna Wydawnicza Politechniki Warszawskiej, Warszawa 2000.

[8] Sen Lin: „Strain Measurment by Digital Image Correlation”, Royal Institute of Technology, Sweden 2015. 